\title{
Research on the Objectives-oriented Driving Mechanism of International Trade Talents Training under the Background of the Belt and Road Strategy*
}

\author{
Yong Yan \\ Business School of Huzhou University \\ Huzhou, China 313000
}

\begin{abstract}
With the implementation of the "Belt and Road" national strategy, new challenges have been encountered in training of internationalized talents for International Trade Major in colleges and universities. However, for the existing talent training mechanism of International Trade Major, no adjustments have been made timely and accordingly with the B\&R Strategy, resulting in mismatching of talent supply of colleges and universities and demand of the markets. This paper innovatively proposes an analytical framework for the IPP goal-driven theory, which is driven by three goals: IInternational, P-Practical and P-Professional. Based on the three core competencies of "Foreign Language Application Ability, Professional Practice Ability, and Comprehensive Professional Ability", this paper also systematically analyzes the construction of internationalized talent training system for international trade to make up for the inadequacies of the current international trade talent training mechanism and guarantee talent supply for the implementation of the $B \& R$ strategy.
\end{abstract}

Keywords-Belt\&Road strategy; international trade talents; internationalized training

\section{INTRODUCTION}

The Belt\&Road Strategy is the abbreviation of the "Silk Road Economic Belt" and the "21st Century Maritime Silk Road" Strategy. It starts from the Asia-Pacific Economic Circle in the east, ends at the European Economic Circle in the west, and connects 65 countries in Central Asia, Southeast Asia, South Asia, West Asia and East Africa. And it is now becoming the third largest trade axis in Asia and Europe following the Atlantic Trade Axis and the Pacific Trade Axis. According to the calculation of the World Bank, the current GDP of the countries along the B\&R amounts to USD 20 trillion, accounting for about one-third of the total global GDP; during 2010-2013, the average annual growth rate of foreign trade and foreign investment in $B \& R$

*[Project Fund] This paper is the research output of Zhejiang Provincial Education Science Planning Project "Research of International Trade Talents Training System Based on IPP in the Background of the B\&R Strategy - Taking Zhejiang Province Universities as An Example" (16SCG036) as well as the phasic research output of Ministry of Education Humanities and Social Sciences Research Youth Fund Project "Research of the Internationalized International Trade Talent Training Mechanism Under the B\&R Strategy" (17YJCZH209). countries is respectively $13.9 \%$ and $6.2 \%$, which are $4.6 \%$ and $3.4 \%$ higher than the global average. It is expected that the proportion of the export scale of $B \& R$ countries will increase to around $1 / 3$ in the next decade ${ }^{[1]}$. With the regional economic and trade intercourses and the formation of favorable orders under the B\&R Strategy, colleges and universities should take the initiative to adapt to the new requirements of the $B \& R$ Strategy on the training of internationalized talents on international trade and provide talent guarantee for the implementation of the B\&R Strategy.

\section{NEW REQUIREMENTS OF THE B\&R STRATEGY ON TRAINING OF INTERNATIONALIZED INTERNATIONAL TRADE TALENTS}

Talent is the key for the deepened implementation of the B\&R Strategy. Therefore, it is necessary to analyze the new requirements put forward by the $\mathrm{B} \& \mathrm{R}$ Strategy for internationalized international trade talent training so as to cultivate a group of internationalized international trade talents with international visions who can adapt to the "New Normal" of international trade and take the lead in the B\&R Strategy.

\section{A. Requirements on International Capital Operation Ability}

"National Development Based on Investment" will become the "New Normal" of the B\&R Strategy under the greater strategy of "Go Global". Throughout the 40 years of reform and opening up of China, we have basically followed the principle of "National Development Based on Export". According to statistics from the United States, in 2017, the U.S. trade deficit in goods with China reached USD 375.2 billion, accounting for $46.3 \%$ of the U.S. trade deficit in goods. On March 23, 2018, Donald John Trump, President of the United States, decided to impose a large-scale tariff on commodities of about USD 60 billion exported from China to the United States based on the results of "Section 301 Investigation" for the reason of serious imbalance between China and U.S. trade. It's just an attempt to repeat the trade war between the United States and Japan in the 1980s and make China follow the "Lost Two Decades" of Japan. Compared with "National Development Based on Export", "National Development Based on Investment" is more conducive to China's control of the initiative in the B\&R 
Strategy and has a proliferation effect through the "investment multiplier" [2]. To implement "National Development Based on Investment", colleges and universities are required to train a group of internationalized international trade talents with international capital operation capabilities to effectively carry out international financial investment, mergers and acquisitions, asset securitization, financial derivatives trading and the Internet finance during the implementation of the B\&R Strategy. Such talents will be the scarce resource for the implementation of the $B \& R$ Strategy.

\section{B. Requirements on New-type International Trade Operation Ability}

In the process of the advance of the B\&R Strategy, China's foreign trade has undergone changes in its form from traditional commodity trade to more extensive forms of international trade such as industrial trade, capital trade, cultural trade, knowledge trade and information trade. This will become the "New Normal" for China's foreign trade. To better take the initiative of the countries along the B\&R Initiative, a batch of internationalized international trade talents with new international trade abilities are required to carry out innovative new-type international trade business in countries along the $\mathrm{B} \& \mathrm{R}$ Initiative. This requires colleges and universities to adjust the training programs for international trade talents and focus on cultivating new internationalized international trade talents who are proficient in international investment, cross-border ecommerce, international procurement, Internet finance and other technologies to meet the demands of the B\&R Strategy.

\section{Requirements on Multilingual Cross-cultural Communication Ability}

According to the Roadmap for Chinese Enterprises in B\&R Initiative issued by the State-owned Assets Supervision and Administration Commission (SASAC) of the State Council on July 14, 2015, as of the end of 2014, among over 110 central SOEs under the SASAC, more than 80 have established branches in countries along the B\&R Initiative[3]. It is widely believed by such enterprises that the multilingual cross-cultural communication ability is very important, which is one of the necessary skills for Chinese enterprises to "Go Global" during the implementation of the B\&R Strategy. As required by the B\&R Talent Strategy, new-type internationalized international trade talents are required to master an additional language of the country along the B\&R Initiative other than English. This aims to make effective cross-cultural understanding and communication under the premise of knowing each other's language. It is also the basis for effective international trade under the New Normal. Therefore, it is necessary for colleges and universities to cultivate a batch of multilingual international trade talents who master the local language of the countries along the $\mathrm{B} \& \mathrm{R}$ Initiative, understand local culture and customs and are familiar with international trade rules.

\section{BOTTLENECKS CURRENTLY RESTRICTING TRAININGS OF INTERNATIONAL TRADE TALENTS IN COLLEGES AND UNIVERSITIES}

In the implementation of the B\&R Strategy, most of the students trained in the current International Trade Talent Training System are only familiar with general international trade knowledge, and such talents will be difficult to meet the "new demands" of the B\&R Strategy on international trade talents", which will further limit the speed and scale of international trade development [2]. According to a survey conducted by McKinsey Consulting and Management Co., Ltd., titled Response to Looming Talent Shortage in China, only less than $10 \%$ of international trade graduates in China are sufficiently skilled to work for foreign companies. Most international trade graduates lack cross-cultural communication skills as well as economic globalization visions and are not competent to work for foreign companies. This is the loophole of the B\&R Strategy. With regard to this, it is necessary for colleges and universities to analyze the roots of the "mismatched supply and demand of talents" in the current process of training international trade talents from the perspective of training mechanism.

\section{A. Convergence of Talent Training Objectives and Lack of New-type International Trade Competence}

With the continuous development of China's exportoriented economies and increasing dependence on foreign trade, International Trade has become a pop major in colleges and universities. Presently, more than 700 undergraduate colleges across the country have set up international trade majors, but the training objectives, teaching programs, curriculum settings and other aspects of most colleges and universities tend to be "converged", and fail to address the new needs of the B\&R talent strategy and develop new-type internationalized international trade talents in a pertinent manner. In addition, the availability of newtype international trade capabilities is an important measure of cultivating new-type internationalized international trade talents. However, most colleges and universities only emphasize the teaching of international trade theories and rules, and lack the ability to cultivate new-type international trade abilities of the students, which will result in shortage of new-type international trade talents of China's enterprises when carrying forward the "Go Global" Strategy in the implementation of the B\&R Strategy.

\section{B. Simplex Teaching Approaches and Weak Practical Foreign Trade Abilities}

The cultivation of internationalized international trade talents should be enabled by adopting the "capacity-based" teaching approaches and the "university-industry cooperation" cultivation methods. However, at present generally most of colleges and universities in China adopt indoctrination teaching methods in training of international trade talents, where only the mechanical memory abilities of the students are developed, while the training on the practical abilities and innovation abilities on international trade are still insufficient. In addition, the formulation of the talent training programs fails to integrate the requirements of 
enterprises "going global" on new-type internationalized international trade talents in the process of implementation of the B\&R Strategy of China, and the implementation of teaching processes fail to realize university-industry cooperation on talent training, resulting on serious dislocation between the theory-based international trade talents cultivated by colleges and universities and application-based international trade talents urgently demanded by enterprises "going global".

\section{Low Multilingual Education Level, Insufficient Cross- cultural Communication Ability}

Foreign language is an important tool for international trade. With the advance of the B\&R Strategy, the current language requirements for international trade talents have also changed from the just English to "E+1", which is, English plus a certain minority language of the country along the B\&R Initiative. However, according to statistics, apart from the international trade majors of a few comprehensive key universities, there are few colleges and universities capable of setting up minority language courses for languages of countries along the $B \& R$ Initiative. And the shortage of multilingual international trade talent supply will largely restrict China's economic and trade exchanges with countries along the $B \& R$ Initiative. In addition, the insufficiency of national culture education on countries along the $\mathrm{B} \& \mathrm{R}$ Initiative has resulted in weak cross-cultural communication skills and difficulties in effectively conducting international business negotiations for the students.

\section{INTERNATIONAL TRADE TALENTS TRAINING APPROACH BASED ON IPP TARGET DRIVING MECHANISM}

With the fact that the current international trade talent training mechanism has not made timely adjustments to the new requirements of internationalized international trade talents for the B\&R Strategy, it has failed to effectively cultivate a large number of new internationalized international trade talents that meet the needs of the B\&R international talent strategy. Therefore, it is necessary to take the B\&R Strategy as the background, and Outline for the National Medium- and Long-Term Education Reform and Development Plan (2010-2020) as the guideline to innovatively construct the IPP goal-driven mechanism. IPP is the abbreviation of the English terms of "International, Practical \& Professional". The abbreviation means to cultivate the new internationalized international trade talents with the three core competencies of "bilingual application ability, professional practical ability and comprehensive professional ability" with the goal of "International, Practical \& Professional".

\section{A. Highlighting Bilingual Application Ability Oriented in Internationalizations}

Based on the B\&R talent strategy and the talent demand of companies "going global", the internationalization of international trade talents should be reflected in the strengthening of bilingual application capabilities and crosscultural communication capabilities. Presently, most colleges and universities adopt the "English + Professional" composite form in training of internationalized international trade talents and the internationalization is mainly oriented in western countries in Europe, America, etc. However, with the implementation of the B\&R Strategy, "E+1+ Professional" will become the New Normal for the internationalization of international trade talents. To be specific, while mastering English, the students are supposed to master an additional minority language of the countries along the B\&R Initiative and be able to make international business communication in a bilingual manner. The demand for such bilingual internationalized international trade talents will continue to rise along with the promotion of the B\&R Strategy. Therefore, accelerating the development of bilingual internationalized international trade talents has become the top priority. In addition, the development of cross-cultural communication skills is also imminent. At present, foreign language communication at a purely technical level can no longer satisfy the actual needs. External communication and cooperation rely more and more on the mutual understanding and identification of both sides in the ideological and cultural aspects. Therefore, cross-cultural communication is an indispensable part of the current reduction in risk costs and the effectiveness of cooperation decision [4]. Countries along the B\&R Initiative have diversified cultures and customs. It is necessary to set up cross-cultural courses such as national conditions and ethnic groups of countries along the B\&R Initiative, and gradually incorporate such courses into the compulsory education system so as to enhance the cross-cultural communication skills of international trade talents.

\section{B. Taking Practice as a Starting Point and Paying Attention to Professional Practice Ability}

The B\&R talent strategy requires that internationalized international trade talents not only have a solid theoretical foundation for international trade, but also have the ability to carry out new types of international trade in various complex environments. The practice-based development of international trade talents should be centered on cultivating new-type international trade abilities of the students. On the one hand, colleges and universities can make full use of and integrate campus resources, and conduct simulation trading and Practice for Operational Competence in International Business (POCIB) with the International Trade Simulation Laboratory as a platform so as to allow students to experience various aspects of international trade and strengthen the practical operation ability on international trade; on the other hand, colleges and universities should positively work on university-industry cooperation with local enterprises "going global" under the B\&R Strategy, invite high-quality foreign trade talents of enterprises "going global" to conduct case teaching on a regular basis, and take real cases of national economic and trade cooperation along the B\&R Initiative as examples to tutor the students practical experience and skills on international trade in a face-to-face manner. In addition, post practice is the most important form of cognitive practice. Colleges and universities should take the initiative to build practice bases with 1 with local foreign trade enterprises "going global" under the B\&R Strategy, 
send students to enterprises in batches on a regular basis, allow students to reach out to real foreign trade business at zero distance, apply theories to practice, and improve the actual operation capacity on foreign trade.

\section{Strengthening Comprehensive Professional Ability Aiming at Professionalization}

It is the due responsibility and required ability for colleges and universities to comprehensively enhance the abilities of national open economic strategy. The manifestation of such responsibility and ability is to train professionalized international trade talents to serve the national B\&R Strategy [2]. Therefore, the strengthening of comprehensive professional ability is one of the important links in the training of internationalized international trade talents. The professionalization of internationalized international trade talents is specifically reflected in the cooperation between universities and Sino-foreign joint ventures, multinational corporations and foreign institutions participating in the B\&R Strategy in form of talent orders, and to train professional internationalized international trade talents in the form of joint training by colleges/universities and enterprises. This requires colleges and universities to take professionalization as the goal in the process of formulating professional training programs for international trade, and to disintegrate and reintegrate the comprehensive professional capabilities of the students in a hierarchical manner into the curriculum teaching system, thereby realizing the enhancement of comprehensive professional competence of the students. In addition, colleges and universities may also apply the examination content of professional qualification certificates related to international trade throughout the training process of international trade talents, so that the contents of professional education can be integrated with the examination content and occupation requirements of professional qualification certificates. And professional knowledge, professional competence and professional quality should be combined to align talent training standards with the needs of the industry and enterprises [5].

\section{CONCLUSION}

In recent years, China's academic circles have achieved fruitful results in research on international trade talent training. The basic consensus is that the international trade talent training mechanism is currently not highly internationalized and has failed to effectively train a large number of "three-in-one" internationalized international trade talents with foreign language application abilities, professional practice abilities and comprehensive professional abilities so as to satisfy the demands of B\&R international talent strategy. The basic reason is that the current international trade professionals training mechanism has not been timely adjusted to the new requirements of the B\&R Strategy for internationalized international trade talents. In addition, the research on the internationalization of international professional talents in combination with the background of B\&R Strategy is still at the initial stage. This paper is based on IPP goal-driven theory, which is driven by three goals: I-International, P-Practical and P-Professional. Based on the three core competencies of "Foreign Language Application Ability, Professional Practice Ability, and Comprehensive Professional Ability", this paper also aims to systematically construct the internationalized talent training system for international trade to make up for the inadequacies of the current international trade talent training mechanism and meanwhile guarantee talent supply for the implementation of the B\&R strategy.

\section{REFERENCES}

[1] Zhai Zhenyuan. "The Construction of B\&R Initiative and the New Mission of National Education" [N]. Beijing: Guangming Daily, 2015-08-13(11).

[2] Wen Jun and Jiang Xianling. "Innovation of Training Path of Internationalized Talents for the B\&R Initiative in Colleges and Universities with Systematic Thinking" $[\mathrm{J}]$. International Business (Journal of University of International Business and Economics), 2015(05).

[3] Hua Yedi. "The Roadmap of B\&R Initiative for Central SOEs Is Issued"[N]. Beijing: Economic Daily, 2015-7-15 (07).

[4] Chen Haiyan. "Implementation of B\&R Strategy and Training of New-type Internationalized Talents"[J]. China Higher Education Research, 2017(06).

[5] Wang Shuyun and Liu Xuewen. Innovation of Training Model for International Trade Talents Oriented to the Social Demands [J]. China Adult Education, 2011(13) 